\title{
JUDICIAL ASSISTANCE FOR THE FOREIGN "TRIBUNAL"
}

The judicial assistance available to foreign governmental agencies in the United States was greatly expanded by the 1964 amendments to the federal assistance statute. Most significant was the insertion of the term "tribunal" to define the type of body which could secure aid from the federal courts. Judicial construction of the new term, however, has presented some difficulties resulting in the denial of assistance to foreign states. This note reviews the policy considerations and legislative history relevant to defining "tribunal," and posits factors to be weighed in establishing a more efficacious "tribunal" test.

$\mathrm{T}$ HE EFFICIENT administration of justice sometimes requires the cooperation of a foreign court to obtain testimony, documents or . other evidence. Foreign court assistance in securing evidence in the proper form can often be of critical importance. A refusal to grant aid, or aid rendered in an unusable form, may interfere with, or completely block, the judicial processes.' Because non-compliance with requests for judicial assistance does not constitute a violation of international law, ${ }^{2}$ international judicial cooperation must be founded upon treaties, domestic law or general principles of comity. ${ }^{3}$

United States cooperation in this area has generally been of a more limited scope than that available in the countries of Europe. ${ }^{4}$ ln 1964, however, amendments to section 1782 of the United States Code were enacted to significantly increase federal court assistance available to foreign and international tribunals in securing testimony, statements and documents. ${ }^{5}$ An important change in the law was the

' Lenhoff, Reciprocity and the Law of Foreign Judgments: a Historical-Critical Analysis, 16 LA. L. REv. 465,470 (1956).

2 Id. at 469.

'International judicial assistance is not limited to aid in securing testimony, statements and documents. It may also include executive aid in extradition, the recognition and execution of foreign judgments, the service of documents for a foreign country, and information on foreign law. Jones, International Judicial Assistance: Procedural Chaos and a Program for Reform, 62 YALE L.J. 515, 516 (1953).

'See Id. at 515-18. See generally Columbia UnIversity School of Law Project on

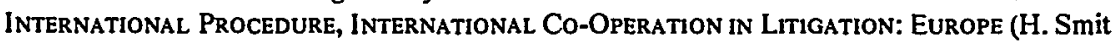
ed. 1965) [hereinafter cited as INTERNATIONAL CO-OPERATION IN LITIGATION].

28 U.S.C. \& I782 (1964). 
replacement of the word "court" with the more general term "tribunal," to describe the type of governmental body which could secure aid under revised section 1782. Judicial construction of the term "tribunal" will determine in large measure the usefulness of the new statute and the attitude of the United States toward international judicial assistance. The policy considerations and legislative history relevant in construing the new term are the subject of this note.

Often testimony, statements and documents can be secured without formal court assistance through depositions or commissions. ${ }^{6}$ Nevertheless, uncooperative witnesses and laws which prohibit private interrogation ${ }^{7}$ frequently necessitate recourse to court aid. Judicial assistance has traditionally been secured through letters rogatory ${ }^{8}$ - formal requests addressed to a foreign judicial authority, usually sent through diplomatic channels, requesting the authority to exercise its power to secure the testimony or other evidence required for a procecding pending in the court requesting aid.'

The majority of nations have entered into treaties which provide for international judicial assistance. ${ }^{10}$ The United States has traditionally refused to enter into such treaties on the ground that, because of our federal system, the subject is too complex to be handled

\footnotetext{
${ }^{6} E . g$. i id. at § 1782(b); Fed. R. Civ. P. 28(b); INTERNATIONAL CO-OPERATION IN LITIGATION 80-81 (English procedures).

${ }^{7}$ See, e.g., Swiss Penal Code art. 271. Art. 271 is interpreted by the Swiss government to prohibit the private interrogation of persons if such interrogation would ordinarily be performed by a Swiss government official. INTERNATIONAL CO-OPERATION IN LITIGATION 365 \& n.15.

'There is some authority to the effect that judicial assistance is never granted in criminal cases. E.g., In re Letters Rogatory From Examining Magistrate of Tribunal of Versailles, France, 26 F. Supp. 852 (D. Md. 1939); In re Letters Rogatory of the Gov't of Italy (Denver, Colo. Dist. Ct., Jan. 12, 1960) reported in International Criminal Law 406 (G. Mueller \& E. Wise eds. 1965); In re Jenckes, 6 R.I. 18 (1859); Letter from United States Circuit Court Judge Morrow to Counsul General of Mexico, April 9, 1909, 3 AM. J. INT'L L. 1011 (1909). Contra, Ex parte Taylor, 110 Tex. 331, 220 S.W. 74 (1920); Mostyn v. Fabrigas, 98 Eng. Rep. 1021, 1029 (K.B. 1774). See generally Mueller, International Judicial Assistance in Criminal Matters, 7 ViLL. L. Rev. 193 (1961-62).

- Jones, Letters Rogatory in Federal Practice in LetTers Rogatory-A Symposium 73 (Grossman ed. 1956). Although American courts tend to think of letters rogatory solely as a means of procuring testimony, e.g., In re Letters Rogatory Out of First Civil Court of City of Mexico, 261 F. 652, 653 (S.D.N.Y. 1919); In re Romero, 56 Mise. 319, 107 N.Y. Supp. 621 (1907), they may also be used to serve summons or a copy of a complaint, conduet an investigation, examine premises involved in litigation, take extracts of books of account, and appoint a temporary administrator of an estate. Jones, supra note 3, at 543-44.

${ }^{10}$ See, e.g., Harvard Research in International Law, Draft Convention on Judicial Assistance, 33 AM. J. INT'L L. 11, 119-28 (Supp. 1939).
} 
by treaty. ${ }^{1 "}$ As an alternative, the United States has promulgated statutes which authorize the federal courts to grant judicial assistance. The first such law, enacted in 1855 , authorized federal courts, in response to letters rogatory, to appoint a commissioner "empowered to compel the witnesses to appear and testify in court." "12 A second, more limited statute, passed in 1863, provided for the execution of letters rogatory only in suits for money judgments involving a foreign government. ${ }^{13}$ Because of the narrow and hostile construction given this statute by the courts, ${ }^{14}$ Congress, in the 1948 revision of the Judiciary Code, provided express permission for the taking of depositions of any person residing in the United States for use in a civil action pending in the court of a foreign country. ${ }^{15}$

Although there are no reported cases interpreting the 1948 statute, commentators noted a number of deficiencies. Procedurally, the statute made no provision for compulsory process ${ }^{16}$ or requests in any form other than depositions, ${ }^{17}$ and the inflexible requirement that federal procedure be followed in the taking of depositions could conceivably have rendered the evidence useless in a foreign court. ${ }^{18}$ Another important restriction limited judicial assistance to proceedings actually pending in a foreign court. This limitation thereby excluded requests in cases not formally initiated, and requests

\footnotetext{
"Jones, supra note 3, at 556-58. One recent exception to American abstinence from judicial assistance treaties is the Convention on the Service Abroad of Judicial and Extrajudicial Documents in Civil or Commercial Matters, open for signatures and signed by the United States Nov. 15, 1965, ratified by the Senate April 14, 1967. 4 lNT'L LeGal Materials 338 (1965). The provisions of this treaty are similar to 28 U.S.C. $\$ 1695$ (1964).

${ }^{12}$ Act of Mar. 2, 1855, ch. 140, § 2, 10 Stat. 630.

${ }^{13}$ Act of Mar. 3, 1863, ch. 95, $\$ 1,12$ Stat. 769.

"See, e.g., Janssen v. Belding-Corticelli, Ltd., 84 F.2d 577 (3d Cir. 1936); In re Letters Rogatory From Examining Magistrate of Tribunal of Versailles, France, 26 F. Supp. 852 (D. Md. 1939); In re Letters Rogatory of Republic of Colombia, 4 F. Supp. 165 (S.D.N.Y. 1933); In re Letters Rogatory from First District Judge of Vera Cruz, 36 F. 306 (S.D.N.Y. 1888); Spanish Counsul's Petition, 22 F. Cas. 854 (No. 13,202) (S.D.N.Y. 1867).

is Act of June 25, 1948, ch. 117, \& 1782, 62 Stat. 949 . A 1949 amendment broadened this statute by deleting the word "residing" and by substituting "judicial proceeding" for "civil action." Act of May 24, 1949, ch. 139, §93, 63 Stat. 103.

16 Jones, supra note 3 , at 542.

"Smit, International Litigation Under the United States Code, 65 Colum. L. Rev. 1015, 1027-28 (1965).

"Jones, supra note 3, at 542; Smit, supra note 17, at 1027-28. For example, interrogation of a witness by anyone other than a judge might make the testimony useless in a court which permitted only judicial interrogation.
} 
from quasi-judicial administrative and investigatory bodies and international tribunals. ${ }^{19}$

A movement to reform United States procedures for judicial cooperation resulted in the congressionally-created Commission on International Rules of Judicial Procedure. ${ }^{20}$ The statutes dealing with judicial assistance were rewritten by the commission ${ }^{21}$ and were enacted verbatim by Congress in $1964 .{ }^{22}$ In the new version of section 1782, federal courts are provided with the discretionary power to order persons residing or found within the district to produce statements, documents or testimony for use in a proceeding in a foreign or international tribunal. The statute permits district courts to follow any procedure prescribed by the tribunal requesting assistance, and expressly allows for the voluntary production of evidence without court intervention. It also stipulates that "[a] person may not be compelled to give his testimony or statement or to produce a document or other thing in violation of any legally applicable privilege." ${ }^{23}$ Furthermore, the term "tribunal," rather than "court," was selected by the drafting committee to cxpand the nature and

19 Jones, supra note 3, at 542; Smit, supra note 17, at 1027. Doubt was expressed as to whether the 1949 amendments allowed for aid to the French juges d'instruction. Jones, supra note 3, at 542; Mueller, supra note 8, at 205. Contra, 4 J. Moore, Federal Practice If 28.09(2) (2d ed. 1967).

${ }^{20}$ Act of Sept. 2, 1958, Pub. L. No. 85-906, 72 Stat. 1743.

21 See generally FOURTH ANNUAL REPORT OF THE COMMISSION ON INTERNATIONAL Rules of Judicial Procedure, H.R. Doc. No. 88, 88th Cong., Ist Sess. (1963) [hereinafter cited as FOURTH ANNUAL REPORT].

${ }^{22} 18$ U.S.C. $\$ 1621$ (1964) (amended to apply to perjury eommitted outside the United States before any person authorized by law to administer an oath); id. at $\$ 3491$ (amended to facilitate the introduction of foreign documents into evidence); 28 U.S.C. $\$ 1696$ (enacted to allow district court cooperation with foreign courts in the service of process within the United States); id. at $\S$ 1741 (amended to comply with FED. R. Civ. P. 44); id. at $\$ 1745$ (amended to facilitate the authentication of foreign patents); id. at $\$ 1781$ (amended to clarify Department of State procedures for transmitting foreign letters rogatory); $i d$. at $\S 1782$ (amended to broaden United States assistance to foreign and international tribunals); id. at $\S 1783$ (amended to provide for the service of federal subpoenas in foreign countries); $i d$. at $\S 1784$ (amended to provide prosecution for contempt as the enforcement machinery for $\$ 1783$ ).

${ }^{23} 28$ U.S.C. \& 1782(a)(1964). The privilege provision, which replaces that formerly found in 28 U.S.C. $\$ 1785$, is another aspect of $\S 1782$ which will require judicial construction. The scope given to the privilege will have a direct bearing upon the usefulness of the statute. In commenting on the scope of the privilege, the committce reports state that there should at least be "a reasonable connection betwecn tbe person asked to produce evidence and the state or country under the laws of which he claims the possible incrimination. Among the factors which the court may consider in determining the existence of such a connection are nationality, domicile, forum, and the place of relevant events." S. REP. No. 1580, 88th Cong., 2d Sess. 11 (1964); Fourth ANNUAL RePORT 52; H.R. REP. No. 1052, 88th Cong., lst Sess. 12 (1963). 
number of governmental bodies eligible for aid under section 1782 . The committee report stated:

The word "tribunal" is used to make it clear that assistance is not confined to proceedings before conventional courts ... . In view of the constant growth of administrative and quasi-judicial proceedings all over the world, the necessity for obtaining evidence in the United States may be as impelling in proceedings before a foreign administrative tribunal or quasi-judicial agency as in proceedings before a conventional foreign court. [Section 1782] therefore provides the possibility of United States judicial assistance in connection with all such proceedings. ${ }^{24}$

The above modifications were intended by the committee to be part of a general liberalization of United States procedures designed to stimulate judicial cooperation in other countries. ${ }^{25}$

${ }^{24}$ Fourth AnNual Report 45; S. ReP. No. 1580, 88th Cong., 2d Sess. 7-8 (1964); H. R. REP. No. 1052, 88th Cong., lst Sess. 9 (1963).

25 "Enactment of the proposed bill into law will constitute a major step in bringing the United States to the forefront of nations adjusting their procedures to those of sister nations and thereby providing equitable and efficacious procedures for the benefit of tribunals and litigants involved in litigation with international aspects. . . .

"The Commission hopes that the initiative taken by the United States in improving its procedures will invite foreign countries similarily to adjust their procedures." FourtH ANNUAl Report 19-20; S. ReP. No. 1580, 88th Cong., 2d Sess. 2 (1964); H. R. ReP. No. 1052, 88th Cong., 1st Sess. 4 (1963).

Letters rogatory have traditionally concluded with a promise to grant similar assistance if requested. Thus, a request for aid is properly made only by a court with sufficient general jurisdiction to be able to perform on the promise. Jones, supra note 3, at 532-33. This requirement of reciprocity has been compared with the role of reciprocity in the recognition of foreign judgments. See In re Letters Rogatory Issued by the Director of Inspection of the Government of India, 385 F.2d 1017, 1022 (2d Cir. 1967). The application of a reciprocity requirement to the recognition of foreign judgments was first enunciated in Hilton v. Guyot, 159 U.S. 113 (1895). In Hilton, the Supreme Court held that an in personam judgment obtained in a foreign court by a foreigner against an American citizen need not be recognized unless the foreign country would recognize a similar American judgment. Id. at 227-28. The limited holding of Hilton has not been reaffirmed by the Court, and the Court has refused to extend the reciprocity requirement. See, e.g., Banco Nacional de Cuba v. Sabbatino, 376 U.S. 398, 412 (1964). In addition, it has becn criticized by commentators. E.g., H. GoOdRICH, CoNfLICT OF LAws 605-08 (3d ed. 1949); Reese, The Status in This Country of Judgments Rendered Abroad, 50 Colum. L. Rev. 783, 793 (1950); Smit, International Res Judicata and Collateral Estoppel in the United States, 9 U.C.L.A.L. Rev. 44, 49-50 (1962).

The holding in Hilton suggests that a possible rationale behind the deeision was to protect American citizens from extensive vuInerability in foreign courts. However, the stated reason was to induce other nations to give conclusive effect to judgments rendered in this country. 159 U.S. at 228. International judicial assistance is not a sub-species of the recognition of foreign judgments. It is not inconsistent to grant assistance in a particular case and then to deny recognition to the judgment issued in the same case. For example, the judgment may have been 
In the first case decided under the 1964 version of section $\mathrm{I} 782$, the Second Circuit focused upon the scope of the term "tribunal." ${ }^{26}$ In the Jain case, the Director of Inspection, the chief officer in the income tax structure of India, sent a letter rogatory to the district court for the Southern District of New York requesting that a commissioner be appointed to secure testimony and documents from two New York banks. ${ }^{27}$ The evidence was to be used by an Indian Income-Tax Officer in the income tax assessment hearing of an Indian citizen. ${ }^{28} \mathrm{~A}$ motion to vacate the order appointing the commissioner, and to quash a

procured by fraud or may be contrary to natural justice or public policy. Reese, supra, at 793800 (1950). Thus, a requirement of reciprocity in the recognition of foreign judgments suggests a similar requirement for judicial assistance only if the rationale supporting the reciprocity requirement in the case of foreign judgments is also appropriate to judicial assistance. However, the need to protect American citizens does not apply to judicial assistance. The statute provides for a discretionary application by district courts, see text accompanying notes 70-71 infra, and granting assistance does not require the recognition of the subsequent judgment. $C f$. Smit, supra note 17 , at $1022-23$. The idea that reciprocity promotes cooperation is likewise questionable. 1t is equally likely to be used as a rationale for retaliation, and, at best, it tends to promote a stalemate. In any case, the committee reports on $\S 1782$ make it clear that the statute was designed to eliminate the reciprocity requirement and to provide for United States initiative in granting assistance. See, e.g., FOURTH ANNUAL REPORT.

${ }^{26}$ In re Letters Rogatory lssued by the Director of Inspection of the Government of India, 385 F.2d 1017 (2d Cir. 1967) [hereinafter referred to as the Jain casel. While the Jain case is the first reported deeision since 1964 which directly considers $\S 1782$, the statute has been used by foreign tribunals. The dockets of the district court for the Southern District of New York list forty-four requests for judicial assistance under $\S 1782$ received in 1964, twenty-five of which were from India. Letter from Jeremiah A. Murphy, Administrative Assistant to the Clerk, Southern District of New York, March 19, 1968, on file in the DUKE LAw JourNal offices.

${ }^{27}$ The United States has entered into a number of tax treaties designed to avoid double taxation, regulate the extent to which foreign tax laws will be enforced by United States courts, and provide for the exchange of information for tax enforcement. E.g., Double Taxation Agreement with Belgium, Sept. 9, 1952, [1953] 2 U.S.T. 1647. A similar treaty with India, which would have covered the Jain case, was signed on Nov. 10, 1959, but was withdrawn by the United States as unacceptable on June 8, 1964. A new treaty was negotiated but has not been signed. CCH TAX Treaties If 3802.

${ }^{2 s}$ Nations and states have frequently refused to allow their courts to be used to enforce foreign tax laws, often citing the rule that a country never takes notice of the revenue laws of another counţry. E.g., Moore v. Mitchell, 30 F.2d 600 (2d Cir. 1929), affd on other grounds, 281 U.S. 18 (1930); Colorado v. Harbeck, 232 N.Y. 71, 133 N.E. 357 (1921); In re Estate of McNecl, 170 N.Y.S.2d 893 (Sur. Ct. 1957); United States v. Harden, 1963 Can. S. Ct. 366; Government of India v. Taylor, [1955] A.C. 491; see Robertson, Extraterritorial Enforcement of Tax Obligations, 7 ARIz. L. REv. 219 (1966). But see Detroit v. Gould, 12 1ll. 2d 297, 146 N.E. 2d 61 (1957); Ohio v. Arnett, 314 Ky. 403, 234 S.W.2d 722 (1950); State v. Rodgers, 238 Mo. App. 1115, 193 S.W.2d 919 (1946). The enforcement of foreign tax laws, however, must be distinguished from the Jain case which involved a request for judicial assistanee in securing evidence to be used by a foreign country to enforce its own tax laws. 
subpoena issued to one of the banks, was denied by the district court. ${ }^{29}$ That court reasoned that the Indian Income-Tax Officer, who decided disputes and was empowered and obligated to act in a quasi-judicial manner, was a "tribunal" entitled to the aid provided by section 1782. ${ }^{30}$ On appeal, the Second Circuit reversed, holding that the Indian Tax Officer was not a tribunal. ${ }^{31}$

The court of appeals developed two arguments in support of its conclusion regarding the nature of the Tax Officer. The first argument focused upon the similarities between the United States and Indian income tax procedures. The court observed that while the United States Tax Court, an "independent agency," would be a tribunal, neither an Internal Revenue agent nor the Appellate Division of the Internal Revenue Service is the type of body Congress would have considered a tribunal under section 1782. ${ }^{32}$ Although IRS agents and the Appellate Division call witnesses, compel testimony, punish for contempt, and are obligated to act fairly and impartially, they "remain tax collectors and not adjudicators." Tax Officer has similar procedural powers with respect to witnesses, and has similar duties of impartiality, "Congress would thus not have expected that 28 U.S.C. $\S 1782$ could be invoked by . . . [the Tax Officer]." ${ }^{34}$

While indeed thcre are some similarities in the powers and duties of Indian $\operatorname{Tax}$ Officers and Internal Revenue agents, there are significant differences between the Indian and United States income tax systems which the court failed to recognize, and which suggest that the Indian Tax Officer is actually more analogous to the United States Tax Court. Unlike the Indian Tax systcm, in which the initial assessment of the tax due is made by the Income-Tax Officer either on the basis of the taxpayer's return or after a hearing, ${ }^{35}$ the United States system is based upon self-assessment. ${ }^{36}$ The procedures of the Internal Revenue Service come into play only if the taxpayer's return is selected for review and a deficiency or inaccuracy is discovered. Conferences with agents in district offices and proceedings before the

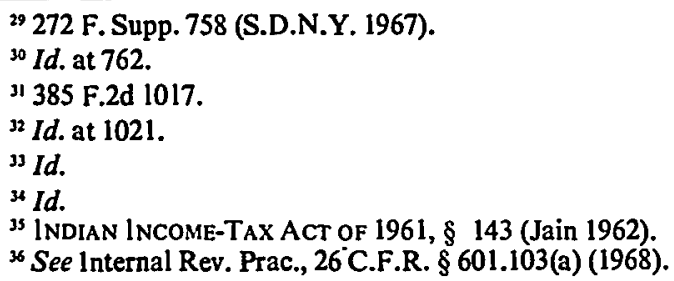


Appellate Division are informal ${ }^{37}$ and the emphasis is upon settlement. ${ }^{38}$ Any assessment made by an agent or the Appellate Division is only a proposal. Unless the taxpayer consents or waives his right of appeal, no collection can be made on the basis of the proposed assessment ${ }^{39}$ and it has no binding effect upon either party. ${ }^{40}$ If the taxpayer's self-assessment is rejected, and he refuses the agent's or Appellate Division's proposed assessment or settlement offer, the actual assessment of tax due is made by the Tax Court. ${ }^{41}$ Thus the informality of the proccedings, the emphasis upon settlement, the provisions for compromise, and the tentative nature of any assessment made by an agent or the Appellate Division contrasts markedly with the procedural aspects of the lndian Tax system. The procedures followed by the Indian Tax Officer are far more formal, ${ }^{42}$ and he has the duty to make a binding assessment subject to appeal only by the taxpayer. ${ }^{43}$ While a superficial comparison might support the findings of the Second Circuit in Jain, these basic differences suggest that the Tax Officer is more analogous to the United States Tax Court.

A second argument relied upon by the court of appeals in denying the Indian Tax Officer's status as a tribunal emphasized the differences between the Tax Officer and the types of bodies Congress intended to include under the term "tribunal." Specifically, the court referred to the French juge d'instruction, whose status as a tribunal is recognized in the Committee reports on section $1782 . .^{44}$ The distinction stressed by the court is that the Tax Officer, in contrast to the juge d'instruction, has the sole responsibility for both making and evaluating the government's case. This "absence of any degree of separation between the prosecutorial and adjudicative functions" is suggested by the court as a useful guideline for distinguishing

\footnotetext{
${ }^{37}$ See id. at $\S 601.106(\mathrm{c})$.

${ }^{38}$ See id. at $\$ \$ 601.105(\mathrm{c})(3), 601.106(\mathrm{~d})$.

${ }^{39}$ INT. REV. CODE OF 1954, \& 6213(a).

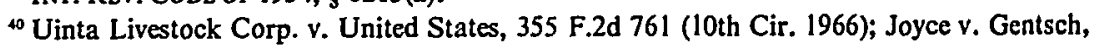
141 F.2d 891 (6th Cir. 1944).

"See Internal Rev. Prac., 26 C.F.R. §601.103(c) (2) (1968).

${ }^{42}$ See notes $57-64$ infra and accompanying text.

${ }^{43}$ INDIAN INCOME-TAX ACT OF 1961, \& 246 (Jain 1962).

4 The committee reports on $\S 1782$ refer to the large number of requests for aid coming from "Investigating Magistrates" and cite to a speech by Lelievre reported in LeTTERS ROGATORY $=\mathrm{A}$ Symposium 9 (Grossman ed. 1956), which discusses the requests for aid from French juges d'instruction. The reports state that "tribunal" is designed to include such magistrates. S. REP. No. 1580, 88th Cong., 2d Sess. 7-8 (1964); Fourth Annual Report 45; H.R. Rep. No. 1052, 88th Cong., 1st Sess. 9 (1963).
} 
administrators who are not tribunals under section 1782 from those who do qualify. ${ }^{45}$ Because the statute is concerned with judicial assistance, this guideline appears to lead to the conclusion that tribunals are predominantly adjudicative bodies.

This test and its application by the court, however, are of questionable validity. The objections stem from the court's misconception rcgarding the functions of the juge d'instruction. The juge, who holds a position in French criminal law roughly analogous to that of a grand jury, conducts the entire investigation of criminal cases including decisions as to the type and scope of investigation to be carried out. ${ }^{46}$ ln so doing the juge constructs the dossier which constitutes the complete basis upon which the decision is made whether or not to prosecute the accused. ${ }^{47}$ However, contrary to the belief of the circuit court, ${ }^{48}$ the juge does not make this decision in any cases other than minor crimes. Rather, the decision is ordinarily made by the Chambre d'accusation. ${ }^{49}$ Thus, it can be argued that the juge d'instruction, by conducting the investigation and compiling the dossier, constructs the government's case against the accused, and that therefore, his function is basically prosecutorial. On the other hand, he does make rulings regarding testimony and evidence, decides what direction the investigation is to follow and what is to be contained in the dossier, and recommends whether the accused should be prosecuted. In these respects his function is adjudicative. If the position of juge d'instruction is viewed broadly in terms of its prosecutorial and adjudicative characteristics, one must conclude that it combines both functions. However, if a predominant function must be identified, it would appear to center around the prosecutorial aspect. In either case, under the test applied by the Second Circuit, the juge would fail to qualify as a tribunal. He would be excluded either because his function was merely prosecutorial, or because it lacked "separation between its prosccutorial and adjudicative aspects." Yet the committee report on section 1782 clearly evidences a congressional intent to include the juge d'instruction as a tribunal..$^{50}$

4s 385 F.2d at 1021.

${ }^{46}$ Anton, L'Instruction Criminelle, 9 AM. J. Comp. L. 44 I, 444 (1960).

${ }^{17} I d$. at 454-55.

48385 F.2d at 1020 .

49 Anton, supra note 46, at 455; Keedy, The Preliminary Investigation of Crime in France, 88 U. PA. L. Rev. 385, 727 (1940); Ploscowe, The Investigating Magistrate (Juge d'Instruction) in European Crininal Procedure, 33 Mich. L. Rev. 1010, 1026-27 (1935).

${ }^{\text {so }}$ See note 44 supra. 
Thus, it would seem that a test which excludes a foreign governmental body from assistance solely because it has some prosecutorial functions, or because it combines both prosecution and adjudication, would conflict with the express intent of Congress in passing section 1782.

Since the prosecutorial-adjudicative test of the appeals court appears inadequate, a new test must be found. The legislative history of the 1964 amendments contains three suggestions regarding the construction of "tribunal." The statement in the committee reports regarding the growing significance of proceedings before "investigating magistrates," "administrative tribunals" and "quasijudicial agencies," and the fact that the statute was designed to provide assistance "in all such proceedings," "s1 makes it clear that section 1782 was not intended to be limited to formal court proceedings. While this statement gives some indication as to the scope of the coverage intended, it provides little assistance in defining "tribunal" in concrete situations.

A second suggestion is found in the committee reference to the 1939 Draft Convention on Judicial Assistance which uses the term "tribunal" in a context similar to section 1782. . $^{\text {s2 }}$ That draft defines "tribunal" as "a judicial authority, or an administrative authority while engaged in the exercise of judicial or quasi-judicial functions ...." ${ }^{3}$ The comments following this definition state that an administrative agency which exercises both administrative and quasijudicial functions is a tribunal "only in connection with an exercise of its quasi-judicial functions . . . ." Since the proper classification of the Indian Tax Officer's one basic function, assessment, is a major issue in Jain, this definition only restates rather than resolves the problem. ${ }^{55}$ Nevertheless, it is helpful when applied to agencies which have more than one basic function. If, for example, an agency was preparing a report for a legislative body, it would not be entitled to use

si S. Rep. No. 1580, 88th Cong., 2d Sess. 7-8 (1964); Fourth ANNuAl Report 45; H.R. REP. No. 1052, 88th Cong., 1st Sess. 9 (1963).

${ }^{32}$ Harvard Research in 1nternational Law, Draft Convention on Judicial Assistance, 33 Ам. J. INT'L L. 15 (Supp. 1939).

${ }^{33} I d$.

st Id. at 39.

ss The court of appeals described the Indian Tax Officer's duties as a combination of prosecutorial and adjudicative functions. $385 \mathrm{~F} .2 \mathrm{~d}$ at 1020-21. Since, however, these functions are an inseparable part of his duties, in that they are performed virtually simultaneously, the analysis suggested by the definition in the Draft Convention cannot be applied. 
section 1782. If, however, the same agency was deciding a dispute or making a ruling, it would be a tribunal and could apply for assistance under the section.

Despite the problems encountered by the Second Circuit, the apparent intention of Congress to include the juge d'instruction within the term "tribunal"s6 may still provide a useful basis upon which to define the scope of aid available under section 1782. Since the juge combines both prosecutorial and adjudicative functions, the test for distinguishing tribunals cannot be whether the body in question is primarily adjudicative. Rather, to structure a proper test, the function of the juge d'instruction must be assessed in light of the manner and context in which he operates. Like a juge therefore, ${ }^{57}$ a tribunal should function in a judicial manner-call and interrogate witnesses, make rulings, collect, analyze and evaluate evidence, and be obligated to act in a fair and impartial manner. Secondly, a tribunal should operate within the context of an actual case or dispute. It should complete its duties by either making a decision regarding the parties before it, or by preparing a case which forms the factual data upon which a ruling affecting the actual parties is made. ${ }^{58}$ The first criterion works to insure that the information sought by judicial assistance will be used in a judicious manner. The second limits judicial assistance to cases which directly affect actual parties.

When these criteria are applied to the Indian Income-Tax Officer, a conclusion opposite that of the Jain court is reached. The Tax Officer works in a judicial manner. ${ }^{59} \mathrm{He}$ must act fairly and impartially, ${ }^{60}$ he calls witnesses, orders them to testify, ${ }^{61}$ punishes for contempt, ${ }^{62}$ follows the basic rules of judicial procedure, ${ }^{63}$ has powers of discovery, ${ }^{64}$ and makes a decision based upon the evidence. ${ }^{65}$ The

\footnotetext{
${ }^{36}$ See note 45 supra.

37 See notes 47-50 supra and accompanying text.

"See Smit, supra note 17, at 1026 n.71.

39 M. Kagzi, The Indian Administrative Law 82 (1962); 1 J. Kanga \& B. Palkhivala, The Law and Practice of 1ncome Tax 638 (5th ed. 1963); M. Kharbanda, commenTARY ON THE INCOME TAX ACT, 1961 at 239 (1963).

$601 \mathrm{~J}$. Kanga \& B. Palkhivala, supra note 59, at 639; M. Kharbanda, supra note 59, at 239.

61 1NDIAN INCOME-TAX ACT OF 1961, § 131 (Jain 1962).

${ }^{62} I d$. at $\$ 136$.

63 M. Kharbanda, supra note 59, at 239; V. Sundaram, The Law of Income-TaX in INDia 806 (9th ed. I963).

4 INDIAN INCOME-TAX ACT OF 1961, § 131 (Jain 1962).

${ }^{65}$ M. KHARBANDA, supra note 59, at 239.
} 
information sought by the Tax Officer is needed to decide a particular case and he concludes his duties by making an assessment of the tax due from a particular taxpayer ${ }^{66}$ Thus, a close comparison of the characteristics of the Indian Tax Officer to those of the juge d'instruction indicates that the Tax Offieer should likewise be included within the scope of section 1782.

In seeking to define "tribunal," there appear to be two conflicting policy considerations troubling the courts. The first is the interest in protecting persons within the jurisdiction of the district court, and the court itself, from undue inconvenience and interruption in having to testify or produce documents and statements. If any foreign governmental body, whether court or agency, eould use section 1782 for any reason, there is a possibility of overuse, indiscretion, invasions of privacy, or general abuse of judicial processes. This consideration, while not overriding, supports a narrow interpretation of section 1782 that limits its use to bodies making determinations in actual cases. ${ }^{67}$

A second policy, one which suggests a broad application, relates to the fact that the 1964 amendments were designed to encourage liberal judicial assistance statutes in other countries. ${ }^{68} \mathrm{~A}$ narrow interpretation of section 1782 would minimize the impact of the statute as an encouragement to the enactment of such statutes by foreign nations. Moreover, the scope afforded section 1782 is likely to influence the interpretation of similar statutes by foreign courts. This impact is most obvious in the case of a decision against cooperation. Although granting assistance under section 1782 in the Jain case would not assure that the Indian courts would respond favorably to an American request (assuming India has a statute similar to section 1782), it would be significant precedent. Alternatively, a refusal of cooperation would surely preclude any assistance for an American tax official. ${ }^{69}$ This consideration suggests that, at a minimum, aid should be given in any case where the United States might need foreign court assistance in a similar situation.

\footnotetext{
${ }^{60}$ INDIAN INCOME-TAX ACT OF 1961, \& 143(3) (Jain 1962).

${ }^{67}$ Even though this policy consideration does suggest a narrow interpretation, it would not preclude a finding that in fact the Indian Income Tax Officer is a tribunal.

${ }^{68}$ Cf. Lenhoff, Reciprocity: The Legal Aspect of a Perennial Idea, 49 Nw. U.L. Rev, 619, 626 (1954); see note 26 supra and accompanying text.

${ }^{69} \mathrm{~A}$ refusal to grant assistance in response to a denial of aid would properly be termed "retorsion"- a lawful act, in response to a legal but undesired act, taken for the purpose of inducing the other state to change its policy. Lenhoff, supra note 68, at 629.
} 
The interpretation of "tribunal" given by the Second Circuit unduly narrows the intended scope of section 1782. While this construction might be rationalized on the ground that it protects United States courts and residents from abusive use of the statute, such a conclusion completely overlooks the statute's explicit discretionary nature. ${ }^{70} \mathrm{~A}$ district court is not obligated to grant every request from each body believed to be a qualified tribunal. The committee reports on the bill make it clear that the district court, in exercising its discretion, may consider the nature and attitude of the country from which the request emanates, as well as the character of the proceedings involved. Furthermore, in granting assistance, the court may impose terms regarding counsel fees, attendance fees for witnesses, fees for interpreters and transcribers and similar provisions. ${ }^{71}$ In close cases, limiting the use of the statute by an exercise of this discretionary power, rather than through a destructively narrow interpretation of "tribunal," would allow for a more flexible and useful statute.

${ }^{10} 28$ U.S.C. $\$ 1782$ (1964).

"S. Rep. No. 1580, 88th Cong., 2d Sess. 7 (1964); Fourth Annual Report 45; H.R. Rep. No. 1052, 88th Cong., Ist Sess. 9 (1963). 